\title{
MANAJEMEN PEMBELAJARAN KITAB KUNING DI PONDOK PESANTREN
}

\section{Heri Khoiruddin}

Universitas Islam Negeri Sunan Gunung Djati Bandung

JI. A.H. Nasution No. 105, Cibiru Bandung, Jawa Barat, 40614

Email: herikhoiruddin@uinsgd.ac.id

\section{Rizki Ikhwan Ferisal}

Universitas Islam Negeri Sunan Gunung Djati Bandung Jl. A.H. Nasution No. 105, Cibiru Bandung, Jawa Barat, 40614 Email: whatsonreef2014@gmail.com

\begin{abstract}
ABSTRAK
Penelitian ini adalah untuk mengetahui manajemen pembelajaran kitab kuning mulai dari perencanaan, pelaksanaan, dan evaluasi di Pondok Pesantren Islam Internasional Terpadu Asy-Syifaa Wal Mahmuudiyyah. Penelitian ini menggunakan pendekatan kualitatif, sedangkan metode penelitiannya adalah metode deskriptif. Teknik pengumpulan data dilakukan dengan teknik wawancara, observasi, dan studi dokumentasi. Sedangkan dalam menganalisis data yang digunakan adalah kategorisasi data dan penafsiran data. Hasil penelitian ini menunjukkan bahwa (1) Perencanaan pembelajaran kitab kuning di Pondok Pesantren Islam Internasional Terpadu Asy-Syifaa Wal Mahmuudiyyah dilakukan dengan membuat daftar pelajaran yang dirumuskan dalam kegiatan rapat dewan guru pada setiap awal semester. Sedangkan untuk materi pelajaran yang akan diberikan kepada santri maka itu diserahkan sepenuhnya kepada pengajar yang bersangkutan; (2) Pelaksanaan pembelajaran kitab kuning dilakukan dengan menyiapkan kelas bagi santri baru dengan membuka long class (kelas jauh) untuk kelas Tahmidi (persiapan) sebelum masuk ke kelas satu. Di kelas jauh tahmidi, santri diberikan pengetahuan tentang bagaimana membaca tulisan Arab dan materi dasar lainnya; (3) Evaluasi pembelajaran kitab kuning dilaksanakan pada tiap akhir semester. Evaluasi tersebut mencakup evaluasi lisan dan tulisan yang mengulas materi pelajaran selama satu semester ke belakang.
\end{abstract}

Kata Kunci : Pembelajaran, Kitab Kuning, Pesantren.

\section{ABSTRACT}

This research is to know yellow book learning management starting from planning, implementation, and evaluation at Islamic International Islamic Boarding School of Asy-Syifaa Wal Mahmuudiyyah. This research uses qualitative approach, while the research method is descriptive method. Technique of data collection is done by interview technique, observation, and documentation study. While in analyzing the data used is data categorization 
and data interpretation. The results of this study indicate that (1) Planning of yellow book study in Pondok Pesantren Islam Internasional Integrated AsySyifaa Wal Mahmuudiyyah done by making a list of lessons formulated in board meeting activities of teachers at the beginning of each semester. As for the subject matter that will be given to students then it is left entirely to the teacher concerned; (2) The execution of yellow book study is done by preparing the class for the new students by opening the long class for the Tahmidi class (preparation) before entering the first grade. In the far-away classes, students are given knowledge on how to read Arabic and other basic material; (3) Evaluation of yellow book study conducted at the end of each semester. The evaluation includes oral and written evaluations that cover the subject matter that has been submitted.

Keywords: Learning, Kitab Kuning, Pesantren.

\section{PENDAHULUAN}

Manajemen pembelajaran menjadi fokus yang harus dikembangkan pesantren sebagai bagian komprehensif pengembangan pesantren, hal ini ditekankan bahwa manajemen pembelajaran menjadi kunci bagaimana keberhasilan proses transfer knowledge dan transfer value pembelajaran pesantren yang khas. Proses belajar mengajar merupakan interaksi yang dilakukan antara guru dan peserta didik dan sumber belajar pada suatu lingkungan belajar. Proses pembelajaran perlu direncanakan, dilaksanakan, dinilai, dan diawasi agar terlaksana secara efektif dan efisien (Rusman, 2011, h. 4).

Pembelajaran kitab kuning di Pondok Pesantren Islam Internasional Terpadu Asy-Syifaa Wal Mahmuudiyyah mengkaji berbagai macam kitab yang termasuk ke dalam kitab klasik karangan para ulama mazhab Syafi'iyyah. Pembelajaran kitab kuning tersebut dilaksanakan di berbagai tingkatan kelas, mulai dari tahmidi $B$, tahmidi $A$, satu, dua, tiga, dan empat. Untuk tiap kelas mempunyai pengajar yang berbeda-beda, disesuaikan dengan jenjang kajian kitab kuningnya dan semua santri diwajibkan mengikuti pembelajaran kitab kuning tersebut. Untuk tingkatan kelas tahmidi, maka kitab kuning yang diajarkan masih berupa dasar seperti kitab jurumiyah untuk nahwu, kitab safinah untuk fiqh, kitab aqidatul awam untuk tauhid, dan kitab hidayat almustafid untuk tajwid. Setelah menyelesaikan kitab-kitab tersebut di kelas tahmidi, maka santri beranjak menuju kelas satu yang terdapat kitab-kitab lanjutan dari kelas tahmidi, seperti kitab mukhtasor imriti dan alfiyah untuk nahwu, kitab fathul qarib untuk fiqh, kitab tijan ad-durory untuk tauhid, dan kitab mukhtasor yaqulu untuk shorof. Begitu pula seterusnya dan berlanjut sampai kelas sembilan dan khattam mengkaji semua kitab kuning yang diajarkan di Pondok Pesantren Asy-Syifaa. Untuk saat ini hanya terdapat empat kelas ditambah kelas tahmidi sebagai kelas persiapan sebelum masuk kelas satu.

Pada tahap perencanaan pembelajaran jangka panjang, Pondok Pesantren Asy-Syifaa Wal Mahmuudiyyah membuat jadwal pelajaran dan daftar wali kelas yang dirumuskan pada setiap awal semester melalui kegiatan rapat dewan guru. Namun khusus untuk rencana pembelajaran semisal RPP dan Silabus yang merupakan bentuk perencanaan tertulis dan menjadi pegangan 
bagi setiap pengajar tidak dibuat oleh pihak pesantren. Selain itu, pada tahap pelaksanaan pembelajaran, santri yang baru masuk seringkali mengalami kesulitan dalam mempelajari kitab kuning, dikarenakan mereka tidak mempunyai dasar yang kuat untuk mempelajari kitab kuning secara langsung, seperti lemahnya kemampuan baca tulis Al-Qur'an.

\section{KAJIAN TEORI}

Manajemen berarti proses, cara, perbuatan mengelola, atau proses melaksanakan kegiatan tertentu dengan mengerahkan tenaga orang lain. Sedangkan pembelajaran adalah segala kegiatan yang dilakukan guru untuk memudahkan siswa mencapai tujuan pembelajaran yang telah ditetapkan (Purwadarminta dalam Ramli, 2015, h. 3). Dengan demikian dapat disimpulkan, bahwa manajemen pembelajaran pesantren merupakan kegiatan dalam melaksanakan tindakan untuk menciptakan suasana komunikasi yang edukatif antara guru/ustadz dan siswa/santri yang mencakup segi kognitif, afektif, dan psikomotorik dalam rangka mencapai tujuan pembelarajan yang telah ditetapkan (Ramli, 2015, h. 4).

Dalam pembelajaran, Davis mengatakan bahwa guru sebagai manajer harus merencanakan pembelajaran, melaksanakan pembelajaran, dan mengawasi pembelajaran. Haerana menyimpulkan fungsi manajemen pembelajaran terdiri dari Perencanaan, Pelaksanaan, dan Penilaian (Haerana, 2016, h. 24).

Menurut Majid (2012, h. 17) dalam konteks pengajaran, perencanaan dapat diartikan sebagai proses penyusunan materi pelajaran, penggunaan media pengajaran, penggunaan pendekatan dan metode pangajaran, dan penilaian dalam suatu alokasi waktu yang akan dilaksanakan pada masa tertentu untuk mencapai tujuan yang telah ditentukan. Hal lain yang harus diperhatikan dalam perencanaan pembelajaran yang dilakukan guru adalah perencanaan jangka panjang dan jangka pendek. Perencanaan proses pembelajaran yang baik meliputi silabus dan rencana pelaksanaan pembelajaran (RPP) yang memuat identitas mata pelajaran, standar kompetensi (SK), kompetensi dasar (KD), indikator pencapaian kompetensi, tujuan pembelajaran, materi ajar, alokasi waktu, metode pembelajaran, kegiatan pembelajaran, penilaian hasil belajar, dan sumber belajar (Haerana, 2016, h. 165).

Menurut lampiran Peraturan Menteri Pendidikan Nasional No. 49/ 2007 tentang Standar Pengelolaan Pendidikan oleh Satuan Pendidikan Nonformal pada Pasal 1 ayat 2 tentang bidang kurikulum dan rencana pembelajaran poin c, pada kegiatan pembelajaran setiap pendidik bertanggung jawab terhadap mutu kegiatan pembelajaran untuk setiap program pembelajaran yang diampunya dengan cara: a) merujuk perkembangan metode pembelajaran mutakhir; b) menggunakan metoda pembelajaran yang partisipatif, aktif, inovatif, kreatif, efisien, dan menyenangkan; c) menggunakan fasilitas, peralatan, dan alat bantu yang tersedia secara efektif dan efisien; dan d) memperhatikan sifat alamiah kurikulum dan program pembelajaran, kemampuan peserta didik, dan pengalaman belajar sebelumnya yang bervariasi serta kebutuhan khusus peserta didik (Vivit, 2013, h. 15). 
Oosterhof dan Bloom, Hastings dan Madaus dalam Ahiri (2011, h. 9) mengemukakan bahwa evaluasi pembelajaran dilakukan untuk mendukung pelaksanaan pembelajaran. Evaluasi dalam pembelajaran terdiri atas evaluasi pendahuluan, evaluasi formatif, evaluasi sumatif, dan evaluasi diagnostik. Evaluasi pendahuluan (preliminary evaluations) dilakukan pada hari pertama pembukaan sekolah. Evaluasi ini dimaksudkan untuk meramalkan keseluruhan pembelajaran yang akan berlangsung dalam suatu periode tertentu, biasanya satu triwulan, satu semester, dan/atau dalam satu tahun pelajaran. Biasanya dilakukan oleh guru secara informal dan adakalanya juga dilakukan melalui pengamatan dan wawancara tidak terstruktur mengenai kemampuan, sikap, dan/atau pengenalan identitas siswa. Melalui kegiatan evaluasi seperti ini, guru akan dapat mengetahui karakteristik siswa yang nantinya akan sangat bermanfaat dalam interaksi belajar mengajar di kelas (Ahiri, 2011, h. 9).

\section{METODE PENELITIAN}

Penelitian ini menggunakan pendekatan kualitatif, sedangkan metode penelitiannya adalah metode deskriptif. Teknik pengumpulan data dilakukan dengan teknik: (1) wawancara, (2) observasi, (3) dan studi dokumentasi. Sedangkan dalam menganalisis data yang digunakan adalah kategorisasi data dan penafsiran data. Selanjutnya uji keabsahan data dilakukan dengan cara: (1) perpanjangan keikutsertaan, (2) ketekunan pengamatan, (3) triangulasi, (4) pengecekan teman sejawat, (5) kecakupan referensi, (6) analisis kasus negatif, (7) pengecekan anggota, (8) uraian rinci, (9) auditing kebergantungan, (10) audit kepastian.

\section{HASIL DAN PEMBAHASAN}

Berdasarkan hasil wawancara, observasi, dan studi dokumentasi yang dilakukan di Pondok Pesantren Islam Internasional Terpadu Asy-Syifaa Wal Mahmuudiyyah, maka diperoleh hasil sebagai berikut:

\section{Perencanaan Pembelajaran Kitab Kuning}

Perencanaan pembelajaran kitab kuning di Pondok Pesantren AsySyifaa Wal Mahmuudiyyah dilakukan melalui rapat yang dihadiri oleh seluruh dewan pengajar pada tiap awal semester. Rapat yang dilakukan pada awal semester ini antara lain untuk membahas dan menentukan wali kelas untuk setiap tingkatan kelas, merancang jadwal pelajaran untuk setiap kelas, jadwal ujian akhir semester, tata tertib untuk santri, dan program atau agenda penting lainnya yang akan dilaksanakan di semester yang akan datang. Rapat tersebut juga dihadiri oleh seorang notulen yang bertugas mencatat setiap hal yang dibahas dan diputuskan dalam rapat tersebut. Hasil yang telah disepakati dalam rapat tersebut kemudian diserahkan kepada Pimpinan Pondok/Abuya untuk diaudit.

Tabel 1

Daftar wali kelas Banin tahun ajaran 2017-2018

\begin{tabular}{|c|l|l|}
\hline No & \multicolumn{1}{|c|}{ Kelas } & \multicolumn{1}{c|}{ Nama Mu'allim } \\
\hline 1 & Tahmidi B1 & Muhammad Yasin \\
\hline 2 & Tahmidi B2 & Muhammad lqbal \\
\hline
\end{tabular}




\begin{tabular}{|c|l|l|}
\hline No & \multicolumn{1}{|c|}{ Kelas } & \multicolumn{1}{c|}{ Nama Mu'allim } \\
\hline 3 & Tahmidi A1 & H. Asep Turmudzi Hasan \\
\hline 4 & Tahmidi A2 & Ahmad Khairi \\
\hline 5 & 1 (satu) & Deden Mauludin \\
\hline 6 & 2 (dua) & Muhammad Didin Zainuddin \\
\hline 7 & 3 (tiga) & Muhammad \\
\hline 8 & 4 (empat) & Muhammad Taufik \\
\hline 9 & 5 (lima) & Maulana Ja'far Shadiq \\
\hline
\end{tabular}

Tabel 2

Daftar Mu'allim dan Kitab yang Diampu

\begin{tabular}{|c|c|c|}
\hline No & Nama Mu'allim & Kitab Kuning yang Diampu \\
\hline 1. & $\begin{array}{l}\text { H. Asep Hasan } \\
\text { Turmudzi }\end{array}$ & $\begin{array}{l}\text { a. Hidayat al-Mustafid } \\
\text { b. Syarh Jazariyyah } \\
\text { c. At-Tibyan } \\
\text { d. Mukhtashor Tashrif dan Qiyas }\end{array}$ \\
\hline 2. & Deden Mauludin & $\begin{array}{l}\text { a.Qowaid Al-Imla } \\
\text { b.Tijan Ad-Durori } \\
\text { c. Jauhar Kalamiyyah } \\
\text { d.Muhammad Al-Insan Al-Kamil } \\
\text { e.Bidayah Al-Hidayah }\end{array}$ \\
\hline 3. & Muhammad Yasin & a. 'Aqidatul 'Awaam \\
\hline 4. & Muhammad lqbal & $\begin{array}{l}\text { a. Arba'in Al-Mukhtashoroh } \\
\text { b. Matn Safinah }\end{array}$ \\
\hline 5. & Muhammad Husain & $\begin{array}{l}\text { a. Qawaid Al-Imla } \\
\text { b. Mukhtashor Imriti dan Alfiyyah } \\
\text { c. Hidayat Al-Mustafid }\end{array}$ \\
\hline 6. & Muhammad Khoiri & $\begin{array}{l}\text { a. At-Ta'rifat dan Matn Jurumiyyah } \\
\text { b. Arba'in Al-Nawawiyyah } \\
\text { c. Mukhtashor Imriti dan Alfiyyah } \\
\text { d. Mukhtashor Yaqulu dan Alfiyyah } \\
\text { e. Ilmu Faraid }\end{array}$ \\
\hline 7. & Muhammad & 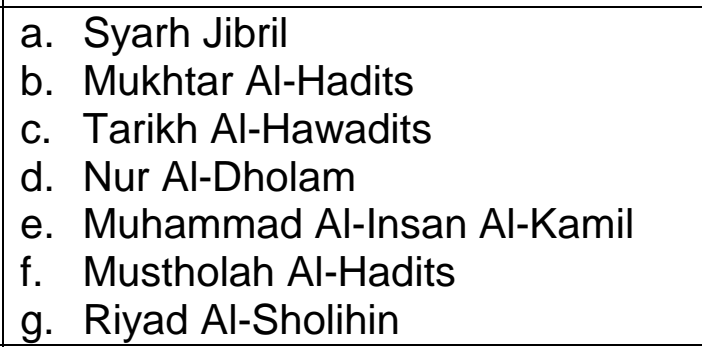 \\
\hline 8. & Maulana Ja'far Shadiq & $\begin{array}{l}\text { a. Mukhtar Al-Hadits } \\
\text { b. Riyad Al-Sholihin } \\
\text { c. Ilmu Faraid } \\
\text { d. Mustholah Al-Hadits }\end{array}$ \\
\hline 9. & $\begin{array}{l}\text { Muhammad Didin } \\
\text { Zainuddin }\end{array}$ & \begin{tabular}{|ll} 
a. Fathul Qorib \\
b. Syarh Jazariyyah
\end{tabular} \\
\hline
\end{tabular}




\begin{tabular}{|l|l|l|}
\hline No & \multicolumn{1}{|c|}{ Nama Mu'allim } & \multicolumn{1}{c|}{ Kitab Kuning yang Diampu } \\
\hline & & $\begin{array}{l}\text { c. Durus Al-Balaghoh } \\
\text { d. Fathul Mu'in dan Zubad }\end{array}$ \\
& & $\begin{array}{l}\text { e. Nur Al-Dholam } \\
\text { f. Mabadi' }\end{array}$ \\
\hline 10. & Muhammad Taufiq & a. Nurul 'Uyun \\
& & b. Kifayah Al-Atqiya \\
& & c. Syarh Jurumiyyah \\
& & d. Fathu Robbil Bariyyah \\
& e. Kailani \\
& f. Yaqulu \\
& g. Mustholah Al-Hadits \\
& h. Durus Al-Balaghoh \\
\hline
\end{tabular}

Perencanaan yang dilakukan terhadap kegiatan pembelajaran kitab kuning di Pondok Pesantren ini bukan hanya untuk tingkat satuan waktu pembelajaran semesteran saja, tetapi juga dilakukan untuk tingkat satuan waktu harian. Perencanaan ini lebih menjadi tanggung jawab Mu'allim/Mu'allimah yang mengampu mata pelajaran/dirosah tertentu dan mempunyai kegiatan rutin mengajarkan kitab kuning kepada santri. Bentuk perencanaan yang dimaksud adalah seperti kegiatan menyiapkan materi yang akan diberikan kepada santri pada pertemuan selanjutnya, sebagai kelanjutan dari pertemuan yang telah dilakukan hari ini.

Namun dibalik semua itu, masih terdapat kekurangan dalam hal perencanaan jangka panjang, yaitu perencanaan yang sifatnya tertulis hanya mencakup jadwal pelajaran dan daftar pengajar saja, sementara RPP dan Silabus tidak dibuatkan. Hal ini tentu sangat penting mengingat apabila ada satu saja materi yang belum tersampaikan kepada santri dalam satu semester, maka mu'allim tidak perlu kebingungan dan hanya perlu melihat silabus dan RPP. Dalam menyikapi permasalahan tersebut pihak pesantren sudah menyerahkan sepenuhnya kepada Mu'allim yang mengajar tentang apa saja yang akan menjadi pembahasan dalam setiap pertemuannya, yang terpenting jadwal yang sudah dibentuk dan disepakati bersama bisa dijalankan dengan baik. Hal tersebut bisa dimaklumi selama tujuan dari pembelajaran bisa tercapai dan evaluasi yang dilaksanakan dapat sejalan dengan apa yang diberikan selama ini kepada santri

Perencanaan pembelajaran umum bahwa perencanaan proses pembelajaran yang baik meliputi silabus dan rencana pelaksanaan pembelajaran (RPP) yang memuat identitas mata pelajaran, standar kompetensi (SK), kompetensi dasar (KD), indikator pencapaian kompetensi, tujuan pembelajaran, materi ajar, alokasi waktu, metode pembelajaran, kegiatan pembelajaran, penilaian hasil belajar, dan sumber belajar", tentu tidak sepenuhnya bisa diterapkan pada lembaga pendidikan seperti pesantren. Pesantren memiliki karakteristik tersendiri yang tentu berbeda dengan lembagalembaga pendidikan umum lainnya. Jika pada umumnya guru memerlukan RPP dan Silabus sebagai acuan untuk mengajar, maka dalam pembelajaran kitab kuning yang diselenggarakan di pesantren dengan adanya jadwal pelajaran dan 
daftar pengajar yang pasti saja sudah cukup untuk dilaksanakannya kegiatan pembelajaran. Artinya bahwa perencanaan dalam bentuk jadwal pelajaran dan daftar pengajar sudah mengakomodasi segala kebutuhan pengajar kaitannya dengan bahan ajar yang mesti diberikan kepada santri.

\section{Pelaksanaan Pembelajaran Kitab Kuning}

Pembelajaran kitab kuning dilaksanakan setiap hari kecuali hari ahad yang merupakan hari libur pesantren. Pada hari-hari tersebut, kegiatan pengajian dilakukan didalam kelas dan dibimbing langsung oleh Mu'allim dan Mu'allimah yang mempunyai bagian untuk mengajar. Pada prosesnya, kegiatan pembelajaran dalam sehari hanya berlangsung tiga kali tatap muka, yaitu pertama kegiatan pembelajaran dimulai pada pukul 08.00-09.45 pagi. Kemudian setelah itu disambung kembali pada pukul 10.15-12.00, kecuali pada hari jum'at khusus untuk banin jam pembelajaran ini dihilangkan karena dipakai untuk shalat jum'at. Terakhir, kegiatan pembelajaran dilakukan pada pukul 16.30-17.30. Semua itu berlaku untuk semua kelas, dimulai dari kelas Tahmidi B sampai dengan kelas 5 , dan berlaku baik untuk banin maupun banat.

Metode yang digunakan Mu'allim dan Mu'allimah didalam kelas untuk mengajarkan kitab kuning kepada santri (Banin dan Banat) yaitu dengan menggunakan metode Bandongan. Metode ini digunakan dengan alasan bahwa santri yang terdapat di Pondok Pesantren Asy-Syifaa Wal Mahmuudiyyah sangat banyak dan sangat tidak memungkinkan untuk digunakan metode sorogan. Metode bandongan yang pada praktiknya melibatkan beberapa orang santri dalam suatu halaqah dan dipimpin oleh seorang Mu'allim yang membacakan teks Arab dalam kitab kuning dan terjemahannya sekaligus makna yang terkandung didalamnya, bersamaan dengan itu santri mendengarkan dan mencatat setiap hal penting yang disampaikan oleh Mu'allim.

Pelaksanaan pembelajaran kitab kuning di Pondok Pesantren Asy-Syifaa Wal Mahmuudiyyah dilakukan dengan beberapa tahapan, dimulai dengan tahap persiapan yang meliputi kegiatan berdo'a sebelum belajar dengan doa sebagai berikut :

\section{Gambar 1}

Doa sebelum Belajar/Mengajar

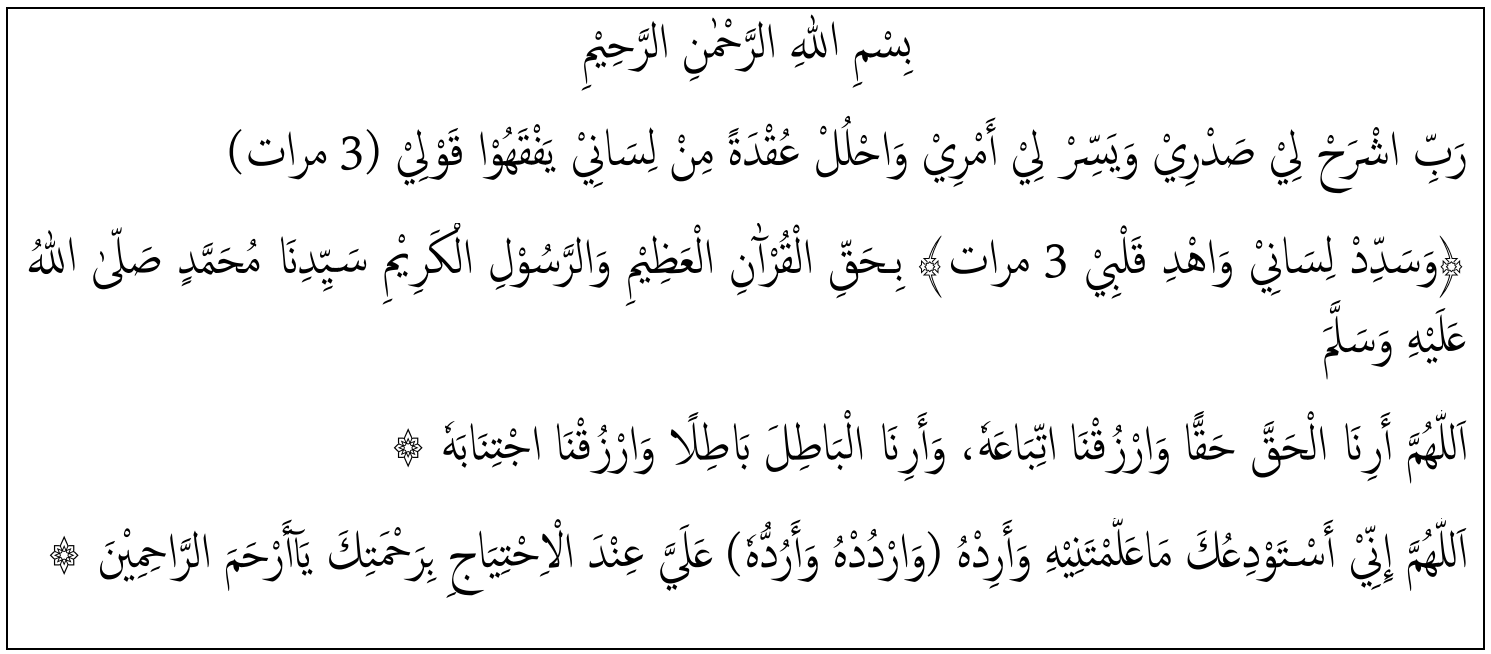




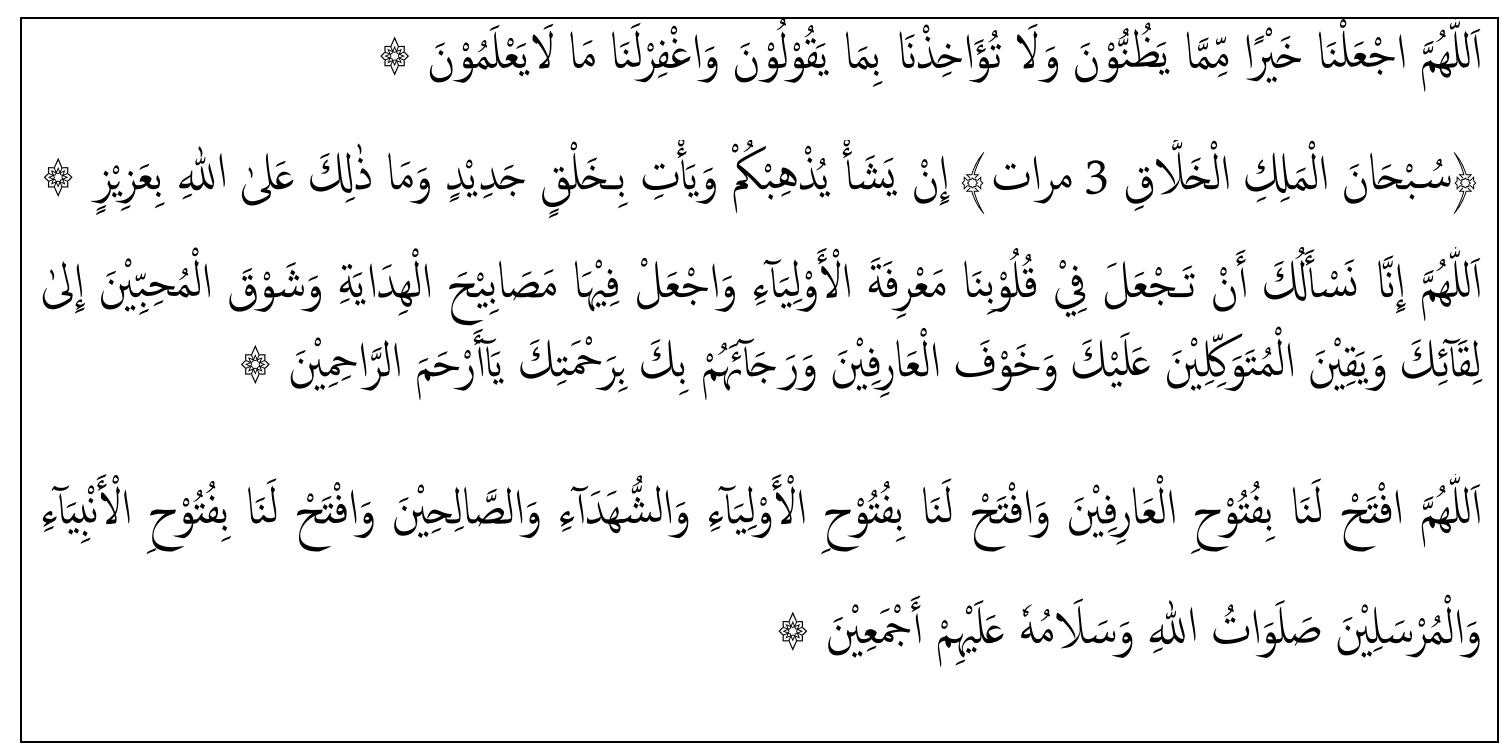

Setelah do'a selesai dibacakan secara serentak, maka selanjutnya Mu'allim mulai mengabsen kehadiran santri. Satu per satu santri disebutkan namanya oleh Mu'allim, kemudian santri mengacungkan tangan seraya mengucap kata "hadir" sebagai jawabannya. Sedangkan untuk santri yang tidak dapat hadir dikarenakan sakit, maka harus memberikan surat keterangan sedang sakit yang ditanda tangani oleh pengurus asrama. Bentuk peraturan lainnya untuk santri yang tidak hadir tanpa keterangan sampai tiga kali dalam satu semester yaitu santri tersebut tidak akan naik kelas sampai tahun berikutnya. Kebijakan tersebut berlaku jika santri tersebut sudah berulang-ulang kali melakukannya dan pihak pesantren sudah tidak bisa lagi memberikan toleransi (Hasil Observasi pada tanggal 18 Agustus 2017 dan Hasil Wawancara dengan nomor penelitian W.8).

Tahapan selanjutnya yaitu tahap pelaksanaan, yang ditandai dengan mulai dibukanya kitab kuning oleh para santri. Kegiatan dilakukan santri dengan duduk bersila di lantai yang dilapisi oleh karpet sambil menggunakan meja lipat sebagai tempat untuk mereka menulis. Tetapi sebelumnya, Mu'allim membacakan hadoroh terlebih dahulu sebagai bentuk penghormatan kepada Mushanif atau Pengarang dari kitab kuning itu sendiri. Setelah selesai membacakan hadoroh, Mu'allim melanjutkan dengan membaca matan dan sarah kitab kuning, sekaligus terjemahan berikut penjelasannya. Dalam menyampaikan terjemah dan penjelasan dari kitab kuning, Mu'allim menggunakan Bahasa Indonesia sebagai perantaranya. Hal ini dikarenakan terdapat juga santri yang berasal bukan dari wilayah Jawa Barat dan tidak bisa berbahasa Sunda (Hasil Observasi dan Pengamatan pada tanggal 18 Agustus 2017).

Seorang santri dituntut untuk bisa mencatat dengan cepat setiap hal penting yang disampaikan oleh Mu'allim, karena seorang Mu'allim sudah terbiasa membacakan kitab kuning secara cepat. Dan bagi santri sendiri terutama untuk pesantren yang bercorak salafi, menyela seorang guru merupakan hal yang tidak dianjurkan, baik itu tujuannya untuk menyanggah 
atau hendak meminta mengulangi kalimat. Bagitu pun dengan santri Pondok Pesantren Asy-Syifaa Wal Mahmuudiyyah, khususnya untuk kelas satu ke atas harus sudah terbiasa dengan menulis cepat. Istilah yang biasa digunakan untuk kegiatan menerjemahkan teks Bahasa Arab di dalam kitab kuning yaitu melogat, yang dilakukan dengan menggunakan huruf Arab bagi yang sudah mahir. Proses menerjemahkannya sendiri dilakukan kata per kata, serta menggunakan simbol-simbol khusus berhuruf Arab untuk mempersingkat penulisan. Mu'allim biasa menggunakan media white board untuk menuliskan kesimpulan dari penjelasan terkait materi yang telah disampaikan, yang kemudian akan dicatat oleh santri di buku tulis khusus (Hasil Observasi dan Pengamatan pada tanggal 18 Agustus 2017).

Tahapan terakhir yang dilakukan setelah kitab kuning selesai dibacakan oleh Mu'allim yaitu santri diperintahkan untuk mengulangi bacaan yang telah ia tulis dari awal sampai akhir, dengan Mu'allim sesekali melontarkan pertanyaan kecil untuk menguji pemahaman santri terkait materi yang telah dipelajari. Kemudian sebagai penutup, do'a setelah belajar dibacakan secara bersamasama. Berikut isi do'a tersebut :

\section{Gambar 4.2}

Doa sesudah Belajar/Mengajar

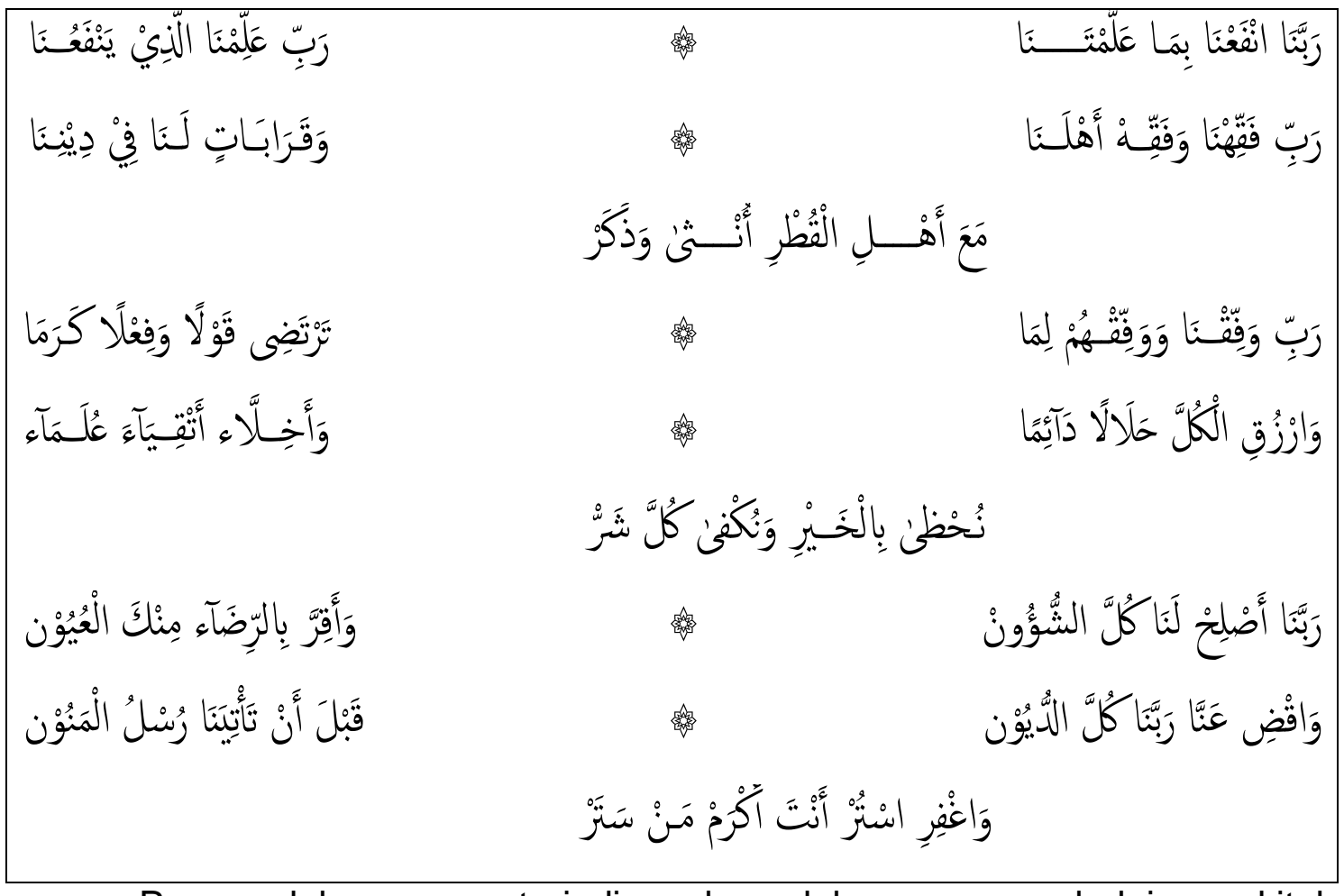

Permasalahan yang terjadi pada pelaksanaan pembelajaran kitab kuning yaitu santri yang baru masuk seringkali mengalami kesulitan dalam mempelajari kitab kuning, sehingga pihak pondok pesantren Asy-Syifaa Wal Mahmuudiyyah membuka long class (kelas jauh) tahmidi (persiapan) bagi santri yang baru bergabung sebelum memasuki kelas satu. Di kelas jauh tahmidi tersebut, santri diberikan materi dasar seperti baca tulis Al-Quran dan hapalan 
kosakata bahasa Arab yang nantinya akan berguna sebagai bekal dalam mempelajari kitab kuning

\section{Evaluasi Pembelajaran Kitab Kuning}

Evaluasi pembelajaran kitab kuning merupakan tahapan penting untuk mengukur sejauh mana pengetahuan santri dalam memahami setiap mata pelajaran yang diberikan lewat perantara kitab kuning. Di Pondok Pesantren Asy-Syifaa Wal Mahmuudiyyah evaluasi dilaksanakan pada waktu yang telah ditentukan oleh pihak pondok pesantren, yaitu pada setiap akhir semester atau enam bulan sekali. Evaluasi tersebut mencakup seluruh dirosah/mata pelajaran selama satu semester, baik yang menggunakan kitab kuning maupun tidak. Secara umum, pelaksanaan evaluasi ini terbagi menjadi dua cara, yaitu: 1) Evaluasi tulisan, yaitu bentuk evaluasi yang menggunakan soal-soal pertanyaan di atas kertas sebagai media penilaian, 2) Evaluasi lisan, yaitu bentuk evaluasi yang dilakukan melalui proses tanya jawab secara langsung antara mu'allim dengan santri. Dari kedua bentuk evaluasi tersebut nantinya akan diakumulasikan menjadi nilai akhir yang kemudian akan menentukan apakah santri tersebut layak naik kelas atau tidak

Ada beberapa aspek yang menjadi tolok ukur keberhasilan santri dalam mempelajari kitab kuning, yang pertama yaitu kemampuan membaca kitab kuning secara baik yang tentunya sesuai dengan kaidah ilmu nahwu dan shorof. Begitu pula di Pesantren Asy-Syifaa Wal Mahmuudiyyah, kemampuan santri dalam membaca kitab kuning menjadi bagian penting yang harus dievaluasi. Untuk itu, pengetesan pembacaan kitab kuning terdapat dalam ujian lisan santri setiap akhir semester, disamping tes hapalan atau talaran matan kitab kuning. Sedangkan untuk aspek pemahaman terhadap kitab kuning lebih menggunakan evaluasi tulisan sebagai sarananya. Dalam evaluasi yang berbentuk tulisan, pertanyaan yang tertera pada lembar soal menggunakan bahasa dan huruf Arab, dan santri harus menjawabnya dengan bahasa dan huruf Arab pula.

Hasil evaluasi kitab kuning pada setiap semester selalu dibukukan dalam buku raport santri yang dikeluarkan sendiri oleh pesantren Asy-Syifaa Wal Mahmuudiyyah, tujuannya adalah agar setiap data nilai yang santri peroleh dari awal masuk pesantren hingga selesai terdokumentasikan dengan baik dan menjadi bukti untuk diperlihatkan kepada orang tua mereka. Selain itu juga, buku raport yang dimiliki santri bisa menjadi parameter perkembangan kemampuan mereka dari tahun ke tahun, khususnya dalam kemampuan mempelajari kitab.

Berdasarkan data evaluasi yang diperoleh dari bagian kepesantrenan bahwa nilai setiap santri pada semua mata pelajaran/dirosah, khususnya yang menggunakan kitab kuning sangat beragam. Pada kelas dua misalnya, secara keseluruhan banyak santri mendapatkan nilai yang tidak jauh dari batas nilai minimum bahkan beberapa orang santri dalam mata pelajaran tertentu menyentuh angka batas nilai minimum. Padahal apabila menurut aturan yang berlaku, jika seorang santri mendapatkan satu saja mata pelajaran yang 
nilainya dibawah batas nilai minimum, maka santri tersebut tidak akan naik kelas. Hal ini menjadi perhatian tersendiri bagi pihak Pondok Pesantren untuk lebih meningkatkan kembali usaha dalam mendidik santri, khususnya dalam hal pengajaran kitab kuning. Salah satu kebijakan yang dibuat pihak Pondok Pesantren yaitu membuat kelas persiapan bagi santri sebelum mempelajari kitab kuning. Kebijakan ini dimulai pada tahun 2015 dan masih terus berlangsung hingga saat ini. Dalam kelas persiapan tersebut yang disebut juga dengan kelas tahmidi, santri diwajibkan menghapal kosakata bahasa Arab sebanyak 10 kata per hari, kemudian setiap hari minggu santri wajib menyetorkan hasil hapalannya tersebut kepada Mu'allim yang menjadi wali kelasnya, sehingga dalam satu tahun santri mampu menghapal kurang lebih 500 kosakata. Selain itu, diberikan juga materi dasar tentang ilmu Nahwu dan Shorof tanpa perantara kitab kuning. Hal ini dilakukan agar nanti pada saat mempelajari kitab kuning, santri sudah mempunyai bekal yang cukup sebagai dasar untuk memahami bagian-bagian tersulit dalam kitab kuning, dan secara tidak langsung akan berpengaruh terhadap nilai mereka (Dokumen Rekap Nilai Raport dan Ranking Banin Semester 1 tahun ajaran 2017-2018 dan Hasil Wawancara dengan nomor penelitian W.4).

Sebagai bentuk bukti pertanggung jawaban pihak pondok pesantren kepada orang tua santri dalam menilai perkembangan putra putri mereka selama belajar di pesantren, maka dibuatlah suatu laporan penilaian dalam bentuk buku. Berikut ini merupakan format isi buku laporan pendidikan Pondok Pesantren Islam Internasional Terpadu Asy-Syifaa Wal Mahmuudiyyah.

Evaluasi pembelajaran kitab kuning merupakan tahapan penting untuk mengukur sejauh mana pengetahuan santri dalam memahami setiap mata pelajaran yang diberikan lewat perantara kitab kuning. Di Pondok Pesantren Asy-Syifaa Wal Mahmuudiyyah evaluasi dilaksanakan pada waktu yang telah ditentukan oleh pihak pondok pesantren, yaitu pada setiap akhir semester atau enam bulan sekali. Evaluasi tersebut mencakup seluruh dirosah/mata pelajaran selama satu semester, baik yang menggunakan kitab kuning maupun tidak. Secara umum, pelaksanaan evaluasi ini terbagi menjadi dua cara, yaitu: 1) Evaluasi tulisan, yaitu bentuk evaluasi yang menggunakan soal-soal pertanyaan di atas kertas sebagai media penilaian, 2) Evaluasi lisan, yaitu bentuk evaluasi yang dilakukan melalui proses tanya jawab secara langsung antara mu'allim dengan santri. Dari kedua bentuk evaluasi tersebut nantinya akan diakumulasikan menjadi nilai akhir yang kemudian akan menentukan apakah santri tersebut layak naik kelas atau tidak.

Pondok Pesantren Asy-Syifaa Wal Mahmuudiyyah melakukan evaluasi hasil belajar santri melalui ujian tulisan dan lisan yang dilakukan pada setiap akhir semester. Kegiatan evaluasi ini menjadi bagian yang tidak terpisahkan dari proses pembelajaran kitab kuning, yang berfungsi untuk mengukur tingkat hapalan dan pemahaman santri. Disamping evaluasi hasil belajar santri, pesantren juga mengadakan evaluasi proses pembelajaran yang biasanya dilakukan pada rapat awal semester. Di dalam rapat tersebut selain membahas materi tentang perencanaan, dibahas pula materi evaluasi proses pembelajaran yang sudah berlangsung selama satu semester ke belakang. 


\section{SIMPULAN}

Berdasarkan penelitian yang dilaksanakan di Pondok Pesantren Islam Internasional Terpadu Asy-Syifaa Wal Mahmuudiyyah Kecamatan Pamulihan Kabupaten Sumedang, maka dapat ditarik kesimpulan sebagai berikut:

1. Kegiatan perencanaan pembelajaran kitab kuning untuk jangka panjang dilaksanakan dalam bentuk rapat pada setiap awal semester. Kegiatan rapat dipimpin langsung oleh Pimpinan Pondok/Abuya K.H. Muhyiddin dan dihadiri oleh seluruh dewan pengajar, bermusyawarah untuk menyusun jadwal pelajaran, menentukan wali kelas, menentukan mu'allim pengampu untuk setiap mata pelajaran, jadwal ujian akhir semester, dan penjadwalan lain untuk agenda-agenda yang akan dijalankan selama satu semester ke depan. Sedangkan kegiatan perencanaan pembelajaran kitab kuning untuk jangka pendek dilakukan Mu'allim tanpa tertulis semisal RPP, melainkan sudah ada dalam benak para Mu'allim dan hanya sebatas perencanaan untuk pertemuan pembelajaran yang akan datang semata.

2. Kegiatan pelaksanaan pembelajaran kitab kuning dilakukan melalui beberapa tahapan. Tahapan pertama merupakan tahap persiapan yang diawali dengan pembacaan do'a sebelum belajar, kemudian santri diabsen satu per satu oleh mu'allim. Tahapan kedua yaitu tahap pelaksanaan yang ditandai dengan pembacaan hadoroh secara bersamasama, kemudian dilanjutkan dengan kegiatan inti yaitu santri mencermati setiap materi yang disampiakan oleh mu'allim dan tentu saja kegiatan melogat kitab kuning sebagai bentuk ciri khas dari pembelajaran kitab kuning. Tahapan terakhir yaitu pengulangan terhadap materi yang telah disampaikan melalui kegiatan tanya jawab antara santri dan mu'allim. Setelah selasai maka ditutup dengan membaca do'a setelah belajar secara bersama-sama.

3. Kegiatan evaluasi pembelajaran kitab kuning dilakukan pada setiap akhir semester atau enam bulan sekali. Evaluasi tersebut mencakup seluruh dirosah/mata pelajaran selama satu semester, baik yang menggunakan kitab kuning maupun tidak. Secara umum, pelaksanaan evaluasi ini terbagi menjadi dua cara, yaitu: 1) Evaluasi tulisan, yaitu bentuk evaluasi yang menggunakan soal-soal pertanyaan di atas kertas sebagai media penilaian, 2) Evaluasi lisan, yaitu bentuk evaluasi yang dilakukan melalui proses tanya jawab secara langsung antara mu'allim dengan santri. Selain dari evaluasi yang dilaksanakan setiap akhir semester, terdapat juga bentuk evaluasi lain semisal evaluasi harian, mingguan, dan bulanan yang dilakukan oleh mu'allim. Namun evaluasi ini bukan menjadi suatu keharusan, melainkan berupa kegiatan tambahan dan tergantung dari kebijakan mu'allim itu sendiri.

\section{REFERENSI}

Rusman. (2011). Model-model Pembelajaran (Mengembangkan Profesionalisme Guru). Jakarta: Rajawali Pers.

Ramli, M. (2015). Manajemen Pembelajaran Di Pondok Pesantren Al Falah Putera Banjarbaru. (idr.iain-antasari.ac.id) diakses pada 3 Agustus 2017. Haerana. (2016). Manajemen Pembelajaran Berbasis Standar Proses Pendidikan. Jakarta: Media Akademi. 
Majid, A. (2012). Perencanaan Pembelajaran (Mengembangkan Standar Kompetensi Guru). Bandung: PT Remaja Rosdakarya.

Arista, V. (2013). Manajemen Pembelajaran di Pondok Pesantren Takwinul Muballighin Yogyakarta. Skripsi tidak dipublikasikan, Yogyakarta: Universitas Negeri Yogyakarta.

Ahiri, J. (2011). Evaluasi Pembelajaran dalam Konteks KTSP. Bandung: Humaniora. 
H. Khoiruddin., R. I. Ferisal 